CURRENT RESEARCH JOURNAL OF HISTORY

(ISSN -2767-472X)

VOLUME 03 ISSUE 01 Pages: 21-25

SJIF IMPACT FACTOR (2021: 5. 505)

OCLC - 1243560778 METADATA IF - 6.458

Crossref do

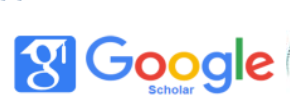

10

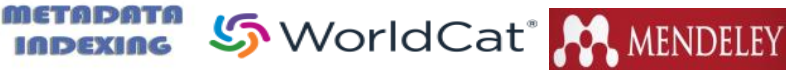

Publisher: Master Journals

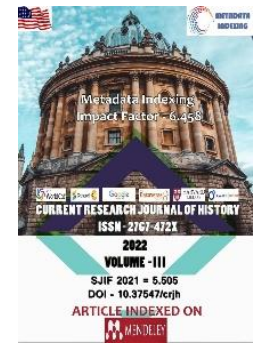

Journal Website: https://masterjournals.

com/index.php/crih

Copyright: Original content from this work may be used under the terms of the creative commons attributes 4.0 licence.
Research Article

\section{PECULIARITIES OF SURKHANDARYA ETHNOCULTURAL CLOTHING}

Submission Date: January 03, 2022, Accepted Date: January 13, 2022, Published Date: January 23, 2022

Crossref doi: https://doi.org/10.37547/history-crjh-03-01-05

\section{Gulrano R. Orifjonova}

Doctor of Philosophy in History (PhD) National Institute of Art and Design named after Kamoliddin Behzod, Uzbekistan

\title{
ABSTRACT
}

This article analyzes the peculiarities of ethnocultural costumes of Surkhandarya oasis. National dress is a manifestation of material culture. The bright colors of the nation, the beautiful art of local weavers developed under the influence of national traditions, the artistic ornaments on the fabrics are reflected in the dress, which is based on the unique centuries-old traditions of each region. Like other regions of Uzbekistan, in the late XIX and early XX centuries, the Uzbek national costume was almost formed in the Southern Surkhandarya oasis. It was revealed that women's clothes are sewn according to their age, differ in color and type of fabric. Each nation has its own national dress, the formation of which depends on the lifestyle of the peoples and the geographical environment is based on scientific analysis.

\section{KEYWORDS}

Clothes, clothing, ethnocultural, paranji, mursak, coat, turban, shoes, jewelry, tissue, fabric.

\section{INTRODUCTION}

National dress is a manifestation of material culture. The bright colors of the nation, the beautiful art of local weavers developed under the influence of national traditions, the artistic ornaments on the fabrics are reflected in the dress on the basis of the unique centuries-old traditions of each region. 
CURRENT RESEARCH JOURNAL OF HISTORY

(ISSN -2767-472X)

VOLUME 03 ISSUE 01 Pages: 21-25

SJIF IMPACT FACTOR (2021: 5. 505)

OCLC - 1243560778 METADATA IF - 6.458

Crossref do
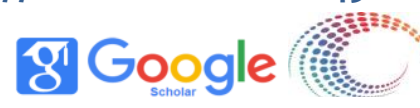

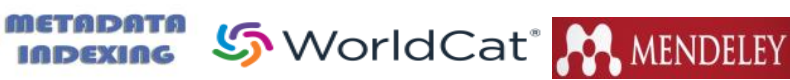

Publisher: Master Journals

One of the biggest factors that shaped the regional types of Uzbek national costumes in the late XIX and early XX centuries is the regional factor. Directly during the khanate period, territorial segregation served to shape identity in clothing.

In addition, there are areas in Uzbekistan where different cultures are mixed. The interplay of these cultures also had a significant impact on clothing. This is clearly seen in the costumes of the Surkhandarya oasis.

\section{MAIN PART}

Surkhandarya's traditional women's dress is distinguished by its bright color. Women's clothing includes: underwear and outerwear, trousers, tops, hats and jewelry.

For casual and holiday wear, women used local, handwoven yarns and semi-silk fabrics such as alacha, boz, janda, and so on. In Boysun, they produced different varieties of alacha called "norposti", "kirmizi", "mazori" and "amiri".

Like other regions of Uzbekistan, in the late XIX and early XX centuries, the Uzbek national costume was almost formed in the Southern Surkhandarya oasis. Women's clothing is tailored to their age, color, depending on the type of fabric and is made of more fabrics such as silk, zarbof, adras, chit, satin. Men's clothes are made of gray, kalami, wool, striped, tik, beqasam.

The women's outer garment was called a "chopon" and was a robe. Unlike the men's chopon, they have an open collar and the tops are cut quite short.

Women's clothing was divided into three types: a shirt with a clearer collar worn as a girl "kiftak" and a dress worn during the wedding as a "bogichi" dress. It is also customary for girls to change their maiden dresses to feminine dresses on their wedding day or on the third day after the wedding.

The uniqueness of women's clothing is especially evident in their hats. Doppies are mostly worn by unmarried young girls and only occasionally by young brides and wives. The edge popugi was a dark red baysuni, a custom to wear rectangular Iraqi doppies. Middle-aged and older women wore a hat called a kulta. The place where the cult was worn on the head was a round, hairpin that fell backwards. In some places it was called a dresser. While the dress was worn by more pastoral rural women, the sedentary rural women wore a "kasava," which was made in the form of a circle of cardboard or several different fabrics, leaving the middle part open.

Another unique type of women's headdress is called a "bosh" or "turban". This hat was mostly worn by kungirat women who had children. The women first wore a half-doppi-shaped dress on their heads and a five- to seven-meter turban over it. The same part of the hat is called the "bosh" and is wrapped around it so that the color of the triangular or rectangular stripes, made of fabrics of different colors and names, from seven to nine, from nine to eleven (sometimes seventeen), is clearly visible. That is why this hat is also called a turban. This hat is called "chambarshah". Between the "bosh" or "turban", the upper part is left open, on which are placed needles, thread, keys, money, handkerchiefs, matches, dry cloth, and so on. This hat is wrapped in a large triangular scarf.

Another peculiarity of these hats, which are sometimes called "bosh", "turban" and "takiya", is that they also reflect the economic situation of the family. For this reason, hats are divided into "boybosh" and "kambagalbosh". "Boybosh" is wrapped in a huge and 
CURRENT RESEARCH JOURNAL OF HISTORY

(ISSN -2767-472X)

VOLUME 03 ISSUE 01 Pages: 21-25

SJIF IMPACT FACTOR (2021: 5. 505)

OCLC - 1243560778 METADATA IF - 6.458

Crossref
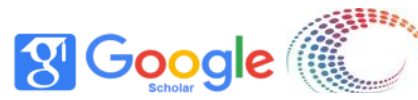

metapmen 5

Publisher: Master Journals

diverse scarf. The handkerchiefs wrapped around the "kambagalbosh" were very simple and scarce [4.71].

There were blankets that covered the hats. Depending on the circumstances, the women always wore something on their heads - jelek, jegda.

Unique regional and local symbols can also be seen in the jewelry and ornaments of the population. Local master jewelers made a variety of jewelry and ornaments.

\section{RESULTS AND DISCUSSIONS}

Each nation has its own national dress, the formation of which depends on the lifestyle and geographical environment of the peoples. In our exhibition there are men's knitted gowns, women's street dresses. The paranji is the dress of the women of the house of officials, which differs from the present fabrics in quality and graceful color. It is a home-sewn fabric decorated with elegant, graceful and attractive shapes and flowers that give a person pleasure. The paranji was used in the late XIX and early XX centuries.

In our country, as well as in the Surkhandarya oasis, the most common men's hats are turbans, doppi and telpak. At the time of the study in the oasis, one of the main headgear was the turban, which was worn by the elderly, self-sufficient and ulama. Again, the turban is surrounded by young men studying in a madrassa and a newly-thinking groom. When the turban is wrapped around the head, one end of the left side is left in front of two, two and a half inches long and tucked up. While praying, the forehead was hung from the side to the chest, and the scholars hung the forehead to the back. In the villages of Maland and Khufor in the Sariosiya district of the oasis, and in the villages of Khanjiza and Khojasoat in the Uzun district, pesh is called dosh. The turbans of the old men were of gray, and the turbans of the young were of dark red. The herdsmen of the oasis wore turbans made of brown cloth from camel's hair and white cloth from white goat's wool.

The style of sewing the doppi differed from each other in terms of decoration, the doppi consisted of avra, lining, jiyak and pilt. Initially, each was sewn separately and then sewn together. In the stitching of the doppi, there were round, sided, ie "kuloh" worn under the turban, as well as rectangular ones, which were worn alone. In the oasis, cattle-breeders also sewed doppi from camel hair for the winter. The people of the oasis, who belong to the kungirat, yuz tribe, called the doppi a hat. Women's outerwear is made of striped fabric and consists mainly of unlined aura. The sleeves, collar and hem of the jacket were embroidered with beautiful fringes, and the women wore the jacket mostly on their heads. Kurta is also found in other regions of Uzbekistan, and is called "ak jada" in Karakalpak and "jada" in Khorezm Uzbeks.

Munisak was the traditional and ancient outer garment of the women of the oasis. Although the method of using munisak is the same, but named differently. In particular, in Bukhara it is called "kaltacha", in Khorezm - "misak", in Tashkent - "mursak", in Fergana - "munsak". In the oasis, the munisak's style of sewing is similar to that of a kurta, with only an aura lining and a wide elbow, and embroidered ornaments sewn on the sleeves of the shirt.

The paranji was the main garment worn by the women of the oasis on the street. The paranji is derived from the Arabic word "farojiya" and became a veil worn mainly on women's heads in the XVI century. The paranji stitching style is similar to a chopon, only the fake sleeves are sewn together so that the two are left at the very back, which means married women. The fact that the tops were not sewn together meant an unmarried girl. These fake feathers were considered 
CURRENT RESEARCH JOURNAL OF HISTORY

(ISSN -2767-472X)

VOLUME 03 ISSUE 01 Pages: 21-25

SJIF IMPACT FACTOR (2021: 5. 505)

OCLC - 1243560778 METADATA IF - 6.458

Crossref do
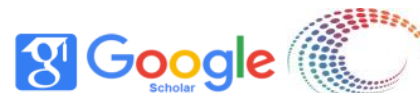
metapmen 5

Publisher: Master Journals

"rituals of the paranji" and the shawl of the paranji was woven in the form of a saddle from the horse's bridle, held to the surface of the shawl and covered with a shawl. In the women's clothing of the Surkhandarya oasis, hats also played an important role. In particular, hats are an integral part of traditional clothing, and it was considered a sin for women to be without hats. Even men did not eat bare-headed food because their "faith" would fly away, thinking that if a woman sat on a meal without a hat, the guardian angels would fly away.

The headscarf was one of the ancient traditional hats of women. The scarf is rectangular in shape and wrapped in different ways. In the oasis, girls began to wear headscarves from the time they reached the age of sin.

\section{CONCLUSION}

In conclusion, it should be noted that the types of Uzbek national costumes, like the types of fabrics, were colorful and in different looks and styles. The dress code is tailored to the age, gender, and casual or ceremonial attire of the population. At weddings and similar ceremonies, women wore two to three layers of dresses. Their skirts and tops were different from each other. The types of women's clothing made up more than the men's clothing. The variety of types of fabrics has made it possible to create special costumes for various ceremonies. For example, the bride's dress for the wedding was made of white, while the women wore blue for the mourning.

The shape of the dress is tailored to make it comfortable to wear and move around.

Young people mostly wore clothes made of colorful, bright colors, while older people wore clothes made of darker, flatter, darker fabrics, while older people wore clothes made of white fabrics. The fabrics of the wealthy were expensive and distinguished from other classes by the frequent use of ornaments. This feature is also noticeable in shoes. The shoes of the rich are decorated with patterns and embroidery. The poor, on the other hand, were distinguished by their simple appearance. The jewelry is decorated with gold and precious stones for the rich, silver and glass for the middle class, and brass and copper for the poor. The clothes were made of imported fabrics and were worn by the rich.

During this period, traditional dresses looked as diverse as fabrics. They are divided into men's and women's clothing. In both groups, the dresses are divided into seasonal and ceremonial dresses, respectively. In men's traditional attire, mostly casual wear took center stage. The shape of the dress made it easy to move. In general, the fabrics and styles of clothes were chosen according to age.

\section{REFERENCES}

1. Abdullaeva U. Women's hats // Echoes from Mazi. - Tashkent: 2011. - № 3. - P. 42.

2. Abdullaeva Sh. Uzbekistan's prestigious fabrics: a new life of tradition // Art magazine. №3. 2015. - P. 32.

3. Binafsha Nadir. The end of the XIX century - the beginning of the XX century Traditional clothes of Khorezm women // Art. - Tashkent: 2009. № 4. - P. 20.

4. Binafsha Nadir. Late XIX - early XX centuries national costumes of the population of the Southern Surkhandarya oasis // Echo of Maziy. - Tashkent: 2003. - № 3-4. - P. 71.

5. Bogoslavskaya I., Levteeva L. Footwear (from the shoe collection of the State History Museum of Uzbekistan) // Art. - Tashkent: 2011. - № 4. - P. 10-14; 
CURRENT RESEARCH JOURNAL OF HISTORY

(ISSN -2767-472X)

VOLUME 03 ISSUE 01 Pages: 21-25

SJIF IMPACT FACTOR (2021: 5. 505)

OCLC - 1243560778 METADATA IF - 6.458

6. Gaybullaeva Y. Women's clothing ornaments (XIX-XX centuries) // Echoes from Mazi. Tashkent: 2016. - № 3. - P. 42.

7. Gaybullaeva Y. From the history of paranji // Echoes from Mazi. - Tashkent: 2011. - № 3. - P. 42.

8. Davlatova S. From the history of Uzbek people's clothes // Echo of Mazi. - Tashkent: 2006. - № 3-4. - P. 6.

9. Sodiqava N. Uzbek national costumes (XIX-XX centuries). -Tashkent: West, 2003.

10. Sukhareva O.A. History of the Central Asian costume: Samarkand - Moscow: Science,1982.

-P. 34 .

11. Orifjonova, G. R. EMBROIDERY ART OF UZBEKISTAN. EPRA International Journal of Multidisciplinary Research (IJMR).

12. Orifjonova, G. R. (2018). ETHNOGRAPHIC COLLECTIONS OF THE STATE MUSEUM OF TEMURIDS'HISTORY: SAMPLES OF ART OF COPPER-EMBOSSING. ISJ Theoretical \& Applied Science, 4(60), 309-312.

13. Orifjonova, G. R. Q. (2019). Ethnographic collections of museums in Uzbekistan: samples of copper-embossing art. Muzeológia a kultúrne dedičstvo, 7(1), 235-240.

14. Inogamov, B. I., \& Khasanov, A. O. (2021). Taking Into Account Socio-Functional Factors in the Design of Housing. Design Engineering, 2587-2589.

15. Орифжонова, Г. (2021). ХОРИж МУЗЕЙЛАРИААГИ ЎЗБЕКИСТОН ЭТНОГРАФИЯСИГА ОИД ЭКСПОЗИЦИЯЛАР ТАХЛИЛИ. Камолиддин Бехзод номидаги Миллий рассомлик ва дизайн институти АХБОРОТНОМАСИ илмий-амалий журнали, 5(02), 140-147.

16. Khasanov, A. (2020). Organizing Eco Tourism Along With Uzbek National Automagistrale
Way. Solid State Technology, 63(6), 1267412678.

17. Орифжонова, Г. Р. (2019). РОЛЬ ЭТНОГРАФИЧЕСКИХ МУЗЕЕВ В ДЕМОНСТРАЦИИ НАЦИОНАЛЬНОЭТНИЧЕСКОЙ КУЛЬТУРЫ. In NATIONAL CULTURES IN SOCIAL SPACE AND TIME (pp. 57).

18. Hwahng, S. J., \& Nuttbrock, L. (2007). Sex workers, fem queens, and cross-dressers: Differential marginalizations and HIV vulnerabilities among three ethnocultural male-to-female transgender communities in New York City. Sexuality Research \& Social Policy, 4(4), 36-59.

19. Odilov, B. A., \& Karimov, N. R. (2020). Analysis of Targeted Research in 20-30 Years of the XX Century. PalArch's Journal of Archaeology of Egypt/Egyptology, 17(6), 8887-8893.

20. Орифжонова, Г. Р. (2021). ВОПРОСЫ СОЗДАНИЯ ЭТНОГРАФИЧЕСКОГО МУЗЕЯ В УЗБЕКИСТАНЕ. In РАЗВИТИЕ СОВРЕМЕННОГО ОБРАЗОВАНИЯ: АКТУАЛЬНЫЕ ВОПРОСЫ ТЕОРИИ И ПРАКТИКИ (рр. 63-65).

21. Inogamov, B. I., \& Khasanov, A. O. (2021). Taking Into Account Socio-Functional Factors in the Design of Housing. Design Engineering, 2587-2589. 